\title{
POTENSI EKSTRAK KASAR ALGA COKELAT (Sargassum sp) DAN DAUN TEH (Camellia sinensis) DALAM MENGHAMBAT OKSIDASI PADA UDANG VANNAMEI (Litopenaeus vannamei) SEGAR SELAMA PENYIMPANAN DINGIN
}

\author{
Potential of Crude Extract of Brown Algae (Sargassum sp) and Tea Leaves (Camellia sinensis) for Inhibits \\ Oxidation of Pasific White Shrimps (Litopenaeus vannamei) During Refrigerated Storage \\ Suci Kusumastuti Nur Azizah, Eko Nurcahya Dewi dan A. Suhaeli Fahmi \\ Program Studi Teknologi Hasil Perikanan, Jurusan Perikanan, \\ Fakultas Perikanan dan Ilmu Kelautan, Universitas Diponegoro \\ Jl. Prof. Soedarto, SH, Tembalang, Semarang \\ E-mail: suci_kna@yahoo.co.id, nurdewisatsmoko@yahoo.com, suhaeli.fahmi@gmail.com
}

Diserahkan tanggal .20 Juli 2017., Diterima tanggal 18 Agustus 2017

\begin{abstract}
ABSTRAK
Penggunaan antioksidan menggunakan bahan alami bertujuan untuk menghambat oksidasi dan memperpanjang masa simpan. Salah satu potensi rumput laut cokelat dan teh yaitu mempunyai kandungan fenol dan flavonoid yang bersifat antioksidan. Produk hasil perikanan seperti udang cepat mengalami proses kemunduran mutu karena kandungan air dan proteinnya yang tinggi. Tujuan penelitian ini adalah mengetahui potensi alga cokelat (Sargassum sp) dan daun teh (Camellia sinensis) dalam menghambat oksidasi pada udang vannamei (Litopenaeus vannamei) selama penyimpanan dingin. Materi yang digunakan dalam penelitian ini adalah alga cokelat, daun teh, dan udang vannamei. Metode penelitian yang digunakan adalah eksperimental menggunakan rancangan acak lengkap (RAL) pola faktorial. variabel yang diamati adalah nilai Angka Peroksida (PV), Thiobarbituric Acid (TBA), Total Volatil Base Nitrogen (TVBN), dan nilai organoleptik. Ekstrak alga cokelat memiliki senyawa fenol dan flavonoid berturut-turut sebesar $1,81 \%$ dan $0,102 \%$ dengan IC50 sebesar 98,236 ppm. Ekstrak daun teh memiliki senyawa fenol dan flavonoid berturut-turut sebesar 0,867\% dan 0,042\% dengan IC50 sebesar 122,673 ppm. Hasil uji untuk melihat tingkat oksidasi lemak yaitu Peroksida Value dan Thiobarbituric Acid menunjukkan ekstrak alga cokelat dan ekstrak daun teh memberikan pengaruh nyata dan dapat menghambat oksidasi pada udang vannamei hingga hari ke - 12. Hasil uji TVBN dan nilai organoleptik menunjukkan ekstrak alga cokelat memberikan pengaruh yang lebih tinggi daripada ekstrak daun teh.
\end{abstract}

Kata kunci: alga cokelat (Sargassum sp.), daun teh, udang, oksidasi, antioksidan

\section{ABSTRACT}

One of the potential of brown seaweed that has phenol and flavonoid compounds that are antioxidants. Tea also contains compounds an antioxidants. The use of antioxidants using natural materials was to prevent oxidation and extend the shelf life. Shrimp highly perishable since the high water and protein contents. The purpose of this research was to determine the potential of brown algae (Sargassum sp) and tea leaves (Camellia sinensis) for inhibiting oxidation of pasific white shrimp (Litopenaeus vannamei) during refrigerated storage. The material that used in this research was a brown algae, tea leaves, and pasific white shrimp. The research method that used was experimental laboratories with the patterns of completely randomized design test with essentially factorial design. Variables value are PV, TBA, TVBN, and organoleptic value. Extracts of brown algae (Sargassum sp) has phenolic compounds and flavonoid compounds were $1.81 \%$ and $0.102 \%$ with IC50 $98.236 \mathrm{ppm}$. Tea leaf extract (Camellia sinensis) has phenolic compounds and flavonoids, respectively for $0.867 \%$ and $0.042 \%$ with IC50 of $122.673 \mathrm{ppm}$. PV value and TBA value results showed brown algae extract and tea leaf extract significant effect and can inhibit the oxidation of pasific white shrimp until 12 days storage. The result of TVBN value and organoleptic value showed brown algae extact gives higher impact than tea leaf extract.

Keywords: brown algae (Sargassum sp.), tea leaves, shrimp, oxidation, antioxidants

\section{PENDAHULUAN}

Sargassum sp mempunyai kandungan nutrisi yang tinggi terutama protein dan mineral. Di samping protein dan mineral, ekstrak S. duplicatum mengandung alkaloid, triterpenoid, steroid, saponin, fenol, flavonoid dan kuinon (Putranti, 2013). Lebih lanjut Firdaus (2013) menyatakan bahwa rumput laut coklat memiliki komponen aktif berupa senyawa fenol yang berpotensi sebagai antioksidan karena

C Copyright by Saintek Perikanan (Indonesian Journal of Fisheries Science and Technology), ISSN : 1858-4748 
mampu memberikan pasangan elektron pada elektron bebas sehingga radikal bebeas dapat diredam.

Teh mengandung senyawa yang disebut katekin. Menurut Putri dan Susanto (2015), ekstrak daun teh hijau segar mengandung antioksidan alami yang dikenal dengan katekin. Ekstrak teh mempunyai kemampuan kuat untuk menangkap peroksida, hidrogen peroksida dan radikal hidroksil. Penangkapan oksigen aktif tersebut dengan ekstrak teh dapat menjelaskan mekanisme antioksidan dan fungsinya sebagai antimutagenik (Rohdiana, 2001).

Oksidasi pada lemak disebabkan oleh pembentukan radikal-radikal bebas. Pembentukan radikal bebas disebabkan oleh adanya faktor yang dapat mempercepat reaksi antara lain cahaya, panas, peroksida lemak atau hidroperoksida, logamlogam berat seperti $\mathrm{Cu}, \mathrm{Fe}, \mathrm{Co}$, dan Mn (Winarno, 2004). Radikal bebas ini dengan oksigen membentuk peroksida aktif yang tidak stabil dan mudah pecah menjadi senyawa yang lebih sederhana sehingga menimbulkan bau tidak sedap.

Antioksidan merupakan zat yang dapat menghambat terjadinya oksidasi pada suatu bahan pangan. Penggunaan antioksidan menggunakan bahan alami bertujuan untuk menghambat oksidasi dan memperpanjang masa simpan. Menurut Rohdiana (2001), adanya antioksidan alami maupun sintesis dapat menghambat oksidasi lipid, mencegah kerusakan, perubahan dan degradasi komponen organik dalam bahan makanan sehingga dapat memperpanjang umur simpan. Penelitian sebelumnya terkait aplikasi senyawa bioaktif pada produk perikanan untuk memperpanjang masa simpan ikan atau hasil pangan lain yang berkadar air tinggi telah dilakukan oleh Husni et al. (2014), perlakuan ekstrak Padina sp dalam mempertahankan mutu filet nila merah selama penyimpanan suhu dingin.

Tujuan dari penelitian ini adalah untuk mengetahui potensi antioksidan ekstrak kasar alga cokelat dan daun teh, serta mengetahui perbedaan pengaruh perendaman ekstrak alga cokelat dan daun teh terhadap udang vannamei selama 12 hari pada penyimpanan dingin.

\section{METODE PENELITIAN}

\section{Persiapan Sampel}

Pada tahap ini dilakukan penanganan sampel, pengeringan, ekstraksi, dan uji untuk mengetahui senyawa bioaktif yang terdapat pada sampel. Sampel alga cokelat (Sargassum sp) diperoleh dari Pantai Krakal, Gunung Kidul, Daerah Istimewa Yogyakarta. Sampel ditempatkan dalam coolbox dengan tujuan supaya suhu tetap terjaga dan tidak terkena sinar matahari secara langsung. Sampel daun teh (Camellia sinensis) berumur 31 bulan setelah tanam diperoleh dari perkebunan teh yang dikelola oleh PT Rumpun Sari Medini yang terletak di Medini, Limbangan, Kendal, Jawa Tengah .

Penanganan kedua sampel diperlakukan sama, sampel Sargassum sp dan daun teh dicuci dengan air tawar untuk menghilangkan kotoran. Kedua sampel kemudian dianginanginkan dalam ruangan yang tidak terkena sinar matahari secara langsung, setelah kering dipotong-potong dan dimaserasi dengan etanol 96\%.

Metode maserasi yang digunakan mengacu pada metode yang digunakan Martinus et al. (2014) dengan modifikasi pada lama maserasi. Metode yang dilakukan yaitu dengan menimbang 100 gram sampel yang sudah dikeringkan kemudian direndam dengan $300 \mathrm{ml}$ etanol 96\% selama 24 jam. Hasil maserasi dikumpulkan kemudian diuapkan dengan rotary evaporator pada suhu $40^{\circ} \mathrm{C}$, sehingga didapatkan ekstrak kental pada masing-masing sampel. Setelah ekstrak masing-masing sampel diperoleh, maka dilakukan beberapa uji antara lain; aktivitas antioksidan, kandungan total fenol, dan kandungan total flavonoid.

\section{Penelitian}

Pada tahap ini udang vannamei direndam menggunakan ekstrak Sargassum sp., ekstrak daun teh, dan kontrol. Penelitian bertujuan untuk mengetahui sejauh mana pengaruh ekstrak alga cokelat dan ekstrak daun teh. Sampel udang vannamei diperoleh dari Mangkang Wetan, Tugu, Semarang, Jawa Tengah. Udang yang diperoleh masih dalam keadaan hidup. Udang diangkut menggunakan box styrofoam dan diberi es supaya suhu tetap terjaga agar udang tidak mati.

Perlakuan yang diterapkan pada udang yaitu udang direndam dengan aquades (kontrol), udang direndam dengan ekstrak Sargassum sp., dan udang direndam dengan ekstrak daun teh. Perendaman yang dilakukan yaitu dengan mengencerkan 10 gram ekstrak Sargassum sp. atau ekstrak dauh teh pada $1000 \mathrm{~mL}$ aquades. Udang dengan berat 20-25 gram/ ekor ( $1 \mathrm{~kg}$ berisi sekitar 40 ekor udang) direndam dalam larutan ekstrak tersebut selama 30 menit. Setelah 30 menit, udang kemudian ditiriskan dan disusun pada styrofoam dilapisi plastik wrap kemudian disimpan pada suhu $8^{\circ} \mathrm{C} \pm 1$ dengan penambahan es batu. Sampel udang yang telah mengalami perlakuan ditentukan kualitasnya berdasarkan pengujian Angka Peroksida (PV), Thiobarbituric Acid (TBA), Total Volatil Base Nitrogen (TVBN), warna, dan organoleptik pada hari ke-0, hari ke-4, hari ke-8, dan hari ke-12.

\section{Prosedur Pengujian \\ Aktivitas Antioksidan (Blois, 1958)}

Uji aktivitas antioksidan menguunakan metode DPPH (1,1-diphenyl 2-picrylhidrazil). Prosedur yang digunakan pada uji DPPH ini menggunakan lima variabel konsentrasi yaitu 0 ppm (blanko), 10 ppm, 20 ppm, 30 ppm, 40 ppm dan 50 ppm, dengan konsentrasi tersebut didapatkan rincian absorbansi. Setelah data $\%$ inhibisi atau $\%$ penangkapan radikal didapatkan, maka berikutnya dilakukan perhitungan untuk mendapatkan nilai $\mathrm{IC}_{50}$ yang merupakan besarnya konsentrasi larutan uji untuk meredam 50\% aktivitas radikal bebas. Nilai $\mathrm{IC}_{50}$ dihitung dari persentase penghambatan atau $\%$ inhibisi larutan ekstrak dengan menggunakan persamaan yang diperoleh dari kurva regresi linier. Pengujian aktivitas antioksidan dengan menggunakan metode DPPH diinterpretaasikan kedalam parameter $\mathrm{IC}_{50}$ atau konsentrasi penghambatan 50. Larutan uji di atas menggunakan larutan DPPH. Konsentrasi larutan sampel akan menyebabkan terjadinya reduksi oleh adanya aktivitas DPPH sebesar 50\%.

\section{Kandungan Total Fenol (Hardiana et al., 2012)}

Uji kadar fenolik menggunakan metode Follin Ciocalteu, sebanyak $1 \mathrm{mg}$ ekstrak ditambahkan $1 \mathrm{ml}$ etanol 95\% dihomogenkan. Setelah itu, diambil 0,1 ml larutan ekstrak tersebut dan ditambahkan $0,1 \mathrm{ml}$ reagen Follin-Ciocalteu 50\%, dihomogenkan dan ditambahkan $2 \mathrm{ml} \mathrm{Na}_{2} \mathrm{CO}_{3} \quad 2 \%$, dan campuran dihomogenkan kembali. Setelah homogen,

\footnotetext{
${ }^{\circ}$ Copyright by Saintek Perikanan (Indonesian Journal of Fisheries Science and Technology), ISSN : 1858-4748
} 
diinkubasikan selama 30 menit. Absorbansi sampel dibaca dengan panjang gelombang $750 \mathrm{~nm}$. Kandungan total fenolik dari ekstrak dihitung dengan menggunakan kurva standar asam galat.

\section{Kandungan Total Flavonoid (Lumbessy et al., 2013)}

Sebanyak 1 g ekstrak Sargassum sp. sampel dilarutkan dalam $100 \mathrm{ml}$ akuades. Larutan disaring, kemudian diambil 1 ml larutan jernih, tambahkan $3 \mathrm{ml}$ larutan $\mathrm{AlCl}_{3}$ 5\%. Akuades ditambahkan hingga volume $10 \mathrm{ml}$. Absorbansi dibaca menggunakan spektrofotometer dengan panjang gelombang $420 \mathrm{~m}$. Kurva kalibrasi dibuat menggunakan standar kuersetin dengan konsentrasi 3, 6, 12, 15, dan 24 ppm. Kadar flavonoid total diperoleh dari persamaan garis kurva kalibrasi yang diperoleh.

\section{Angka Peroksida (Badan Standardisasi Nasional, 1998)}

Uji angka peroksida dilakukan dengan menghaluskan daging udang, kemudian ditimbang masing-masing sebanyak 1 gram. Sampel dimasukkan dalam erlenmeyer tertutup, kemudian ditambahkan $20 \mathrm{ml}$ kloroform. Tahap selanjutnya ditambahkan asam asetat-kloroform dengan perbandingan 3:2 kemudian ditambahkan $1 \mathrm{ml}$ larutan $\mathrm{KI}$ jenuh dan digojong agar sampel dan pereaksi dapat homogen. Erlenmeyer berisi sampel tersebut disimpan pada ruangan gelap selama 30 menit dan ditambahkan $100 \mathrm{ml}$ aquades dan 3-4 tetes larutan pati 1\%, kemudian dititrasi dengan $\mathrm{Na}_{2} \mathrm{~S}_{2} \mathrm{O}_{3} 0,002 \mathrm{~N}$.

\section{Thiobarbituric Acid (TBA) (Apriyantono et al., 1989)}

Ditimbang masing-masing 10 gram sampel yang sudah dihancurkan kemudian ditambahkan $50 \mathrm{ml}$ aquades dan dihancurkan dengan waring blender. Sampel yang sudah hancur kemudian dipindahkan ke labu destilasi dan ditambahkan $\mathrm{HCl} 4 \mathrm{~N}$ serta batu didih dan pencegah buih. Dan didestilasi sehingga diperoleh destilat sebanyak $50 \mathrm{ml}$. Destilat yang diperoleh dipindahkan sebanyak $5 \mathrm{ml}$ ke tabung reaksi tertutup, kemudian ditambahkan $5 \mathrm{ml}$ reagen TBA. Larutan dicampur dan dipanaskan selama 35 menit pada air mendidih. Setelah proses pemanasan, tabung raeksi tertutup dianginanginkan hingga suhu normal, dilakukan pembacaan menggunakan spektrofotometer dengan panjang gelombang $528 \mathrm{~nm}$. Perhitungan TBA yang dinyatakan dalam $\mathrm{mg}$ malonaldehid per Kg sampel. Bilangan TBA=7,8 D.

\section{Total Volatil Base Nitrogen (TVBN) (Badan Standardisasi Nasional, 2009)}

Sampel udang ditimbang sebanyak 10 gram ,dilakukan penambahan $90 \mathrm{ml}$ PCA $6 \%$ dan dihomogenkan. Setelah homogen, filtrat disaring, dimasukkan $50 \mathrm{ml}$ filtrat ke tabung destilasi. Tahap berikutnya dilakukan penambahan 2-3 tetes indikator fenolftalein (PP) dan silikon anti-foaming dan

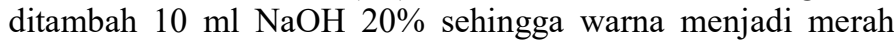
muda. Erlenmeyer yang berisi $100 \mathrm{ml} \mathrm{H}_{3} \mathrm{BO}_{3} 3 \%$ disiapkan, kemudian ditambahkan 3-5 tetes indikator Tashiro hingga warna berubah menjadi ungu. Sampel didestilasi sehingga volume $200 \mathrm{ml}$ dan larutan menjadi berwarna hijau, dilakukan titrasi dengan $\mathrm{HCl} 0,02 \mathrm{~N}$ sehingga warna berubah menjadi ungu.

\section{Penilaian Organoleptik (Badan Standardisasi Nasional, 2006)}

Uji organoleptik dilakukan berdasarkan SNI, dengan scoresheet udang segar. Uji organoleptik merupakan penilaian yamg dilakukan dengan panca indera, sesuai dengan penilaian panelis. Penilaian yang dilakukan dapat dilihat dari kenampakan, bau, dan tekstur.

\section{HASIL DAN PEMBAHASAN}

\section{Rendemen}

Ekstrak Sargassum sp. yang diperoleh berwarna hijau kehitaman pekat, sedikit berbeda dengan ekstrak teh yang berwarna hijau pekat. Hasil nilai rendemen yang diperoleh dari ekstrak Sargassum sp. yang dimaserasi menggunakan pelarut etanol $96 \%$ adalah $1,02 \%$. Hasil yang berbeda ditunjukkan dengan nilai rendemen ekstrak teh yang dimaserasi dengan pelarut yang sama yaitu 7,84\%. Menurut penelitian Khotimah et al. (2013), hasil rendemen Sargassum fillipendula yang didapatkan untuk isolat kuning kehijauan yaitu sebesar $0,33 \%$ dan untuk isolat orange sebesar 0,46\%. Peneliti lain Ananda (2009), menghasilkan nilai rendemen teh hijau sebesar 5,46 persen. Jumlah rendemen masing-masing ekstrak berbeda, hal ini dikarenakan adanya beberapa faktor antara lain; jenis sampel yang digunakan, jenis pelarut, kepolaran pelarut yang digunakan, serta rentang waktu pada saat maserasi.

\section{Kandungan Fenol dan Flavonoid}

Uji fitokimia fenol dan flavonoid yang dilakukan secara kuantitatif. Kandungan fenol pada sampel Sargassum sebesar 1,81\%. Kandungan fenol Sargassum sp. ini lebih besar apabila dibandingkan dengan kandungan fenol pada teh yaitu sebesar $0,867 \%$. Kandungan senyawa fenol yang terdapat pada kedua sampel dapat berfungsi sebagai senyawa antioksidan. Menurut Rafsanjani dan Putri (2015), senyawa fenolik atau polifenolik yang dapat berupa golongan flavonoid, turunan asam sianat, kumarin, tokoferol dan asam-asam polifungsional dapat berfungsi sebagai senyawa antioksidan.

Kandungan flavonoid pada kedua sampel lebih kecil dari pada kandungan fenolnya. Kandungan flavonoid Sargassum sp. adalah 0,102\%. Kandungan flavonoid teh adalah $0,042 \%$.

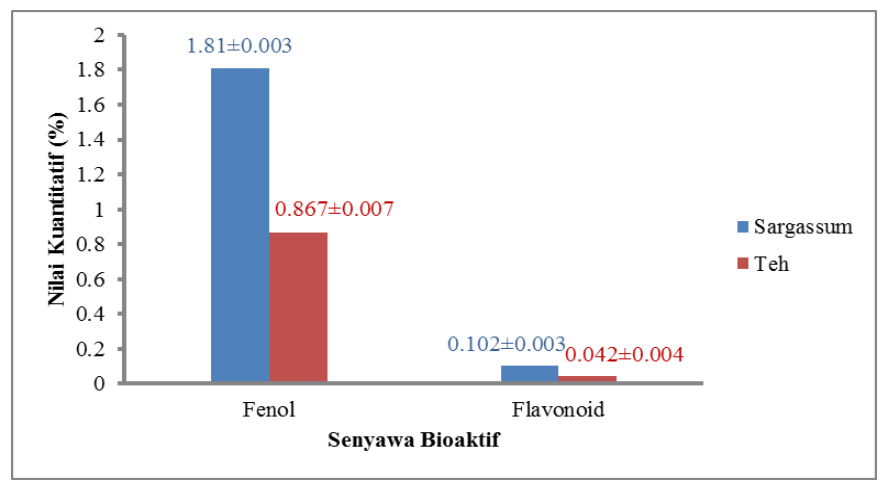

Gambar 1. Prosentase Nilai Fenol dan Flavonoid

\section{Aktivitas Antioksidan}

Berdasarkan hasil uji aktivitas antioksidan menggunakan metode DPPH diperoleh nilai IC $_{50}$ Sargassum 
98,236 ppm. Hal ini menunjukkan hasil ekstrak Sargassum sp. tergolong kuat. Sedangkan, pada sampel teh diperoleh nilai $\mathrm{IC}_{50} 122,673 \mathrm{ppm}$. Ekstrak teh tergolong sedang. Hal tersebut diperkuat oleh pendapat Jun et al. (2003) dalam Samin et al. (2013), suatu senyawa dinyatakan sebagai antiradikal bebas sangat kuat apabila nilai $\mathrm{IC}_{50}<50$ ppm, kuat apabila nilai $\mathrm{IC}_{50}$ antara 50-100 ppm, sedang apabila nilai $\mathrm{IC}_{50}$ berkisar antara 101-250 ppm, lemah apabila nilai IC $_{50}$ berkisar antara 250-500 ppm dan tidak aktif apabila $\mathrm{IC}_{50}$ diatas 500 ppm.

\section{Angka Peroksida}

Angka peroksida pada udang yang direndam dengan Sargassum sp. menunjukkan nilai yang berbeda nyata pada hari ke-8. Namun, nilai ini tidak berbeda nyata dari kontrol maupun perendaman dengan daun teh. Hasil berbeda nyata adalah pada hari ke-12. Perendaman Sargassum berbeda nyata dengan kontrol tetapi tidak berbeda nyata dengan perendaman daun teh. Angka peroksida Sargassum sp. menunjukkan nilai yang berbeda nyata dari kontrol, ada dua kemungkinan yaitu antioksidan dalam Sargassum sp. dapat menghambat laju peroksida atau senyawa aldehid sudah terurai menjadi senyawa malonaldehid dan memasuki tahap kerusakan lemak berikutnya. Menurut pendapat Dewi et al. (2011), angka peroksida tinggi mengindikasikan lemak atau minyak sudah mengalami oksidasi. Angka yang lebih rendah bukan selalu berarti menunjukkan kondisi oksidasi masih berjalan pada tahap awal tetapi dimungkinkan produk hasil oksidasi lemak sudah terurai menjadi senyawa lain pada tingkat lanjut.

Oksidasi dapat terjadi karena adanya kontak antara oksigen dan lemak. Oksidasi berawal dari terbentuknya peroksida pada lemak akan terus bertambah selama waktu penyimpanan. Peroksida yang terbentuk merupakan suatu indikasi ketengikan awal yang terjadi pada bahan pangan. Bahan pangan dikatakan tengik apabila sudah melewati batas angka peroksida. Khotimah et al. (2013), menunjukkan bahwa peroksida merupakan suatu tanda adanya pemecahan atau kerusakan pada minyak karena terjadi oksidasi (kontak dengan udara), yang meyebabkan bau/aroma tengik pada minyak. Penelitian Aminah (2010), juga menunjukkan bahwa peroksida dapat mempercepat proses timbulnya bau tengik dan flavor yang tidak dikehendaki dalam bahan pangan. Jika jumlah peroksida lebih dari $100 \mathrm{meq}$ peroksid/kg minyak akan bersifat sangat beracun dan mempunyai bau yang tidak enak. Sedangkan Huss (1995), menyatakan batas toleransi nilai peroksida tertinggi dalam daging ikan yaitu $10-20 \mathrm{meq} / \mathrm{Kg}$.

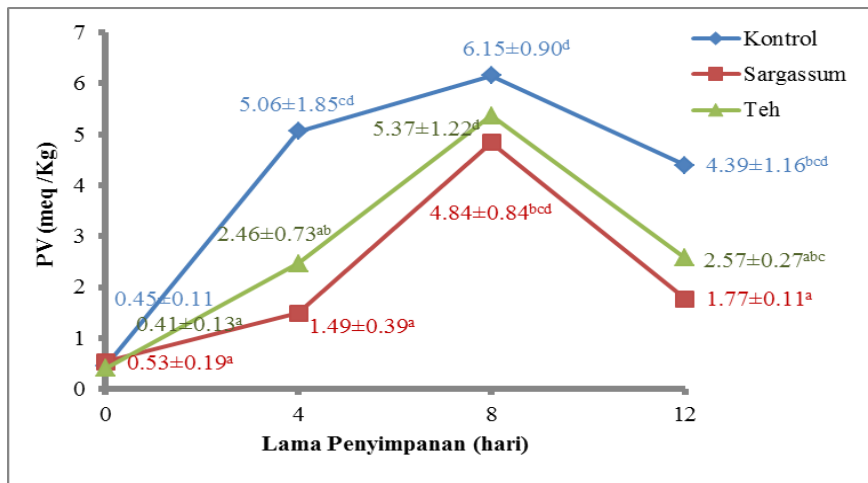

Gambar 2. Hasil PV Udang Selama Penyimpanan Dingin Keterangan :
-Nilai merupakan hasil rata- rata dari tiga kali ulangan \pm standar deviasi

-Data yang diikuti dengan tanda huruf kecil menunjukkan perbedaan yang nyata $(\mathrm{p}<0,05)$.

\section{TBA (Thiobarbituric Acid) Udang Hasil Penelitian}

Nilai TBA pada hari ke-12 mengalami kenaikan berbanding terbalik dengan nilai PV pada hari ke-12 yang mengalami penurunan. Hal ini sesuai dengan teori kerusakan lemak yang menunjukkan hubungan nilai PV dan TBA pada penelitian Sampels (2013), dimana angka peroksida menunjukkan jumlah hidroperoksida yang merupakan produk primer. Namun, peroksida tidak stabil dan sangat reaktif maka diperlukan penanganan secara hati-hati. Peroksida akan terus mengalami kenaikan hingga batas maksimal, tetapi setelah beberapa saat kecepatan reaksi terhadap produk oksidasi sekunder, nilai peroksida akan kembai menurun. TBA bereaksi dengan malonaldehid pada reaksi oksidasi sekunder pada produk.

Perbedaan nyata dapat terlihat pada penyimpanan hari ke-12, dengan nilai 0,035 mg malonaldehid/ Kg. Nilai tersebut menunjukkan nilai yang lebih rendah dari kontrol. Selain nilai TBA yang masih lebih rendah dari kontrol, nilai TVBN pada sampel Sargassum sp. pada hari ke-12 masih dapat dinyatakan layak untuk dikonsumsi. Hal ini diduga Sargasssum sp. dapat mencegah aldehid yang berperan dalam proses ketengikan terurai menjadi senyawa yang lebih sederhana sehingga pembentukan malonaldehid dapat terhambat. Hal tersebut sesuai dengan hasil yang dilakukan Khotimah et al. (2013), pada masa simpan 1 hari didapatkan nilai terkecil yaitu sebesar $4.35 \mathrm{mg}$ malonaldehid/kg minyak, untuk masa simpan 5 hari mengalami penurunan menjadi $3.12 \mathrm{mg}$ malonaldehid/ $\mathrm{kg}$ minyak dan untuk masa simpan 10 hari sebesar $1.74 \mathrm{mg}$ malonaldehid/kg minyak. Hal ini dikarenakan jumlah peroksida yang terbentuk masih kecil akibat dari reaksi senyawa aktif yang ada pada Sargassum fillipendula, sehingga untuk diubah menjadi malonaldehid juga terbatas dan menyebabkan jumlah kadar TBA menurun. Batasan nilai TBA pada produk pangan oleh FDA (Food Drug Administration) US dalam Kurade dan Baranowski (1987) adalah maksimal 1,286 $\mathrm{mg}$ malonaldehid/ $\mathrm{kg}$ bahan.

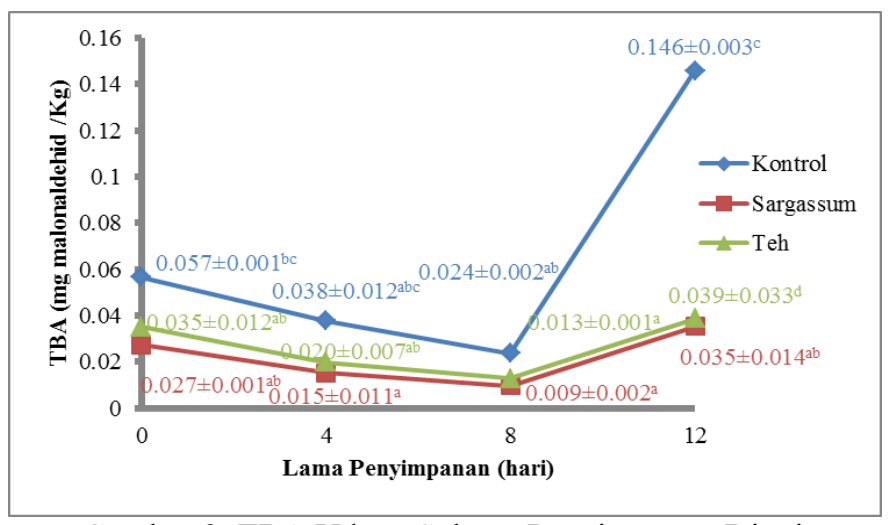

Keterangan :

-Nilai merupakan hasil rata- rata dari tiga kali ulangan \pm standar deviasi

-Data yang diikuti dengan tanda huruf kecil menunjukkan perbedaan yang nyata $(\mathrm{p}<0,05)$. 


\section{TVBN (Total Volatil Base Nitrogen) Udang Hasil Penelitian}

Berdasarkan hasil nilai TVBN pada kontrol mengalami kenaikan berbeda nyata pada pengujian hari ke-0 $(9,13 \mathrm{mg} \mathrm{N} /$ $100 \mathrm{~g})$, hari ke-4 (17,48 mg N/ $100 \mathrm{~g})$, hari ke-8 (29,25 mg N/ 100 g). Hari ke-12, nilai TVBN menunjukkan angka 33,38 mg N/ 100 g. Pola nilai TVBN terus menerus meningkat. Hal ini dikarenakan nilai TVBN menunjukkan tingkat kesegaran ikan yang semakin menurun. Hal tersebut sebanding dengan nilai organoleptik yang semakin menurun dari segi kenampakan, bau, dan tekstur selama penyimpanan. Pada penelitian Suptijah et al. (2008), semakin tinggi nilai TVB menunjukkan mutu daging yang semakin menurun. Hal tersebut juga sesuai dengan penelitian yang serupa tetapi menggunakan sampel filet nila merah yang dilakukan Husni et al. (2014), kandungan TVBN filet nila merah mengalami kenaikan sebanding dengan lama penyimpanan.

Hasil nilai TVBN pada perlakuan perendaman dengan ekstrak daun teh memiliki pola yang sama dengan kedua perlakuan yang lain, yaitu terus meningkatnya nilai TVBN. Perbedaan terjadi pada hari ke-12 yaitu dengan kenaikan yang signifikan sehingga mencapai 59,43 mg N/100 g. Kenaikan yang sangat tinggi menandakan kesegaran udang telah menurun. Hal ini diduga ekstrak teh yang digunakan hanya dapat mempertahankan kesegaran udang hingga sebelum hari ke-12. Namun, pola nilai TVBN dari data yang diperoleh sama antara perlakuan satu dengan yang lain. Susanto et al. (2011) yang meneliti ikan kembung yang diberi perlakuan bahan alami mempunyai tingkat perubahan nilai TVB-N yang berbeda antar perlakuan namun memiliki pola yang sama. Menurut BPPMHP (2005) dalam Dewi dan Ibrahim (2008), menambahkan bahwa ikan masih dikatakan segar apabila nilai TVB-N dibawah 30 $\mathrm{mg} \mathrm{N} / 100 \mathrm{~g}$.

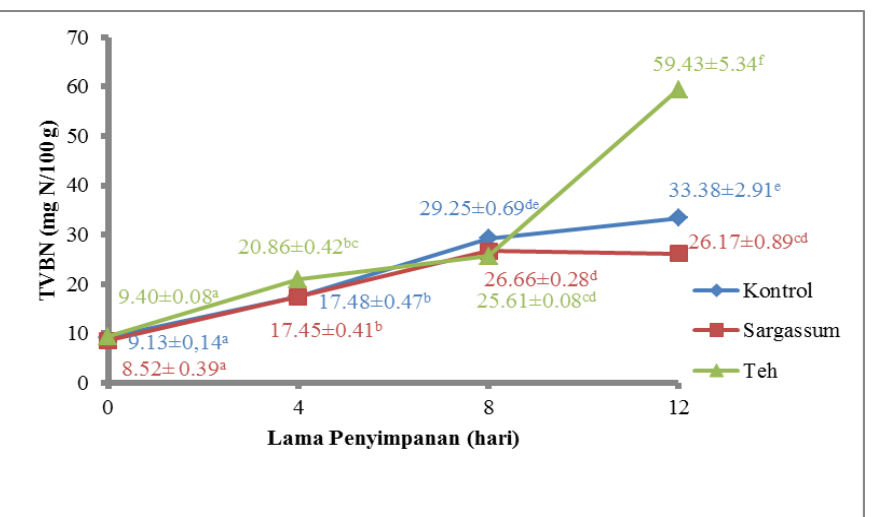

Gambar 4. Grafik Nilai TVBN Udang Selama Penyimpanan Dingin

Keterangan :

-Nilai merupakan hasil rata- rata dari tiga kali ulangan \pm standar deviasi

- Data yang diikuti dengan tanda huruf kecil menunjukkan perbedaan yang nyata $(\mathrm{p}<0,05)$.

Nilai TVBN yang bagus pada hari ke-0 menunjukkan udang masih dalam kondisi segar. Selama penyimpanan kesegaran udang semakin menurun. Hal ini dikarenakan udang telah mengalami degradasi protein akibat aktivitas mikroba dalam udang. Aktivitas mikroba dalam daging udang menghasilkan enzim. Enzim-enzim tersebut menyebabkan terjadinya degradasi protein sehingga menghasilkan senyawasenyawa yang merupakan komponen dari senyawa volatil.
Kesegaran dengan uji TVBN juga didukung oleh warna sampel yang semakin memudar. Pengujian warna menggunakan alat colorimeter, pada hari ke-0 sampel berwarna hijau pekat. Warna hijau menandakan bahwa udang masih dalam keadaan segar. Selama penyimpanan warna hijau tersebut memudar. Hsl ini dikarenakan pigmen klorofil pada sampel diduga semakin menurun selama penyimpanan. Andarwulan et al. (2011), menyatakan bahwa klorofil merupakan pigmen larut lemak yang membentuk warna hijau. Tanaman umumnya mengandung dua jenis klorofil, yaitu klorofil a (memiliki gugus $-\mathrm{CH}_{3}$ ) dan klorofil b (memiliki gugus - CHO). Intensitas warna hijau dari klorofil dapat berubah akibat adanya pemansan, kondisi asam, basa atau aktifitas enzim. Lebih lanjut Rohdiana (2001), menyebutkan bahwa aktivitas antioksidan pada teh selalu dihubungkan dengan adanya katekin.

\section{Nilai Organoleptik}

Berdasarkan hasil rata-rata uji organoleptik dapat dilihat bahwa nilai organoleptik udang semakin menurun selama penyimpanan. Namun, nilai organoleptik pada kontrol lebih cepat menurun daripada nilai organoleptik udang dengan perendaman Sargassum atau teh. Hal ini diduga perendaman menggunakan Sargassum atau teh dapat mempertahankan kualitas udang yang dapat dilihat dari segi organoleptik. Hasil yang sama tetapi menggunakan sampel berbeda juga dikemukakan oleh Susanto et al. (2011), pada kontrol tingkat penurunan nilai organoleptik lebih cepat dibandingkan dengan ikan kembung yang diberi perlakuan bahan alami. Nilai organoleptik yang diberikan berselang antara 1-9. Semakin tinggi rata-rata nilai organoleptik maka semakin segar sampel yang diuji. Batas nilai organoleptik pada sampel segar yaitu 7. Semakin menurunnya nilai organoleptik menunjukkan udang semakin busuk. Menurut Azizah (2015), fase kebusukan (deterioration) yaitu merupakan fase kebusukan pada udang vaname dan sudah tidak layak untuk dikonsumsi. Fase kebusukan (deterioration) hasil pengamatan organoleptik udang yaitu menunjukkan nilai 3-1.

\section{a. Kenampakan}

Kenampakan merupakan hal yang pertama dilihat ketika seseorang ingin membeli atau mengonsumsi bahan makanan. Oleh karena itu kenampakan sangat penting dalam menunjang harga jual bahan makanan tersebut. Penyimpanan pada hari ke - 0 sampel udang masih belum menunjukkan perbedaan yang sangat nyata karena udang baru saja mati dan masih segar. Perbedaan kenampakan dimulai pada penyimpanan hari ke - 4 sampai hari ke -12 . Kenampakan udang dengan perendaman teh memiliki nilai organoleptik paling rendah. Hal tersebut dikarenakan ekstrak teh yang sangat kental sehingga merubah warna udang menjadi kurang menarik.

Udang yang disimpan pada suhu dingin selama 12 hari dapat dilihat secara jelas perubahan dari udang utuh, mulai memerah dan ada noda hitam pada udang tersebut. Penambahan ekstrak Sargassum sp memberikan pengaruh pada kenampakan yaitu dengan tidak terlalu berubahnya kenampakan udang pada saat penyimpanan. Berbeda dengan teh yang memberikan pengaruh pada kenampakan udang. Perubahan kenampakan yang terjadi pada udang menunjukkan adanya kemunduran mutu. Hal ini diperkuat oleh pendapat Utari (2014), tumbuhnya blackspot pada udang merupakan ciri khusus ketika udang mengalami kemunduran mutu. 


\section{b. Bau}

Bahan makanan yang memiliki aroma tidak sedap akan mengurangi selera konsumen. Berdasarkan pengamatan bau pada uji organoleptik, bau amoniak ketiga jenis sampel dapat dirasakan pada penyimpanan hari - 12. Apabila dilihat dari nilai organoleptik, nilai bau pada kontrol yang paling menyengat. Awal penyimpanan bau masih sangat segar spesifik jenis, semakin lama penyimpanan bau menjadi netral dan mulai muncul bau amoniak. Herliany et al. (2013), dalam penelitiannya menyebutkan bahwa kemunduran mutu pada produk perikanan dapat ditandai dengan timbulnya bau tidak sedap (off odor) akibat perombakan protein menjadi senyawasenyawa volatil bebas oleh mikroba pembusuk.

\section{c. Tekstur}

Tekstur daging pada saat pengamatan dapat dirasakan melalui sentuhan. Tekstur daging udang yang direndam Sargassum sp. memiliki kepadatan yang lebih baik dari pada perlakuan yang lain, kemudian nilai tekstur udang yang direndam teh, dan nilai tekstur yang paling rendah adalah kontrol. Tekstur berubah dari kompak, padat, dan elastis hingga menjadi lunak dan tidak elastis selama penyimpanan. Perubahan tekstur menunjukkan adanya kemunduran mutu pada udang. Menurut Utari (2014), serabut otot pada fase pre rigor belum mengalami kerusakan. Serabut otot masih terlihat kompak dan padat. Serabut otot pada fase rigor mortis mulai mengalami pengerutan. Serabut otot pada fase post rigor sudah terpotong-potong.

\section{KESIMPULAN}

Kesimpulan yang dapat diperoleh dari hasil penelitian dan pembahasan adalah ekstrak alga cokelat (Sargassum sp) memiliki senyawa fenol dan flavonoid dalam jumlah yang mampu menghambat oksidasi lemak berturut-turut sebesar $1,81 \%$ dan $0,102 \%$ dengan $\mathrm{IC}_{50}$ sebesar 98,236 ppm, masuk dalam antioksidan kategori kuat. Ekstrak daun teh memiliki senyawa fenol dan flavonoid dalam jumlah yang mampu menghambat oksidasi lemak berturut-turut sebesar $0,867 \%$ dan 0,042\% dengan $\mathrm{IC}_{50}$ sebesar $122,673 \mathrm{ppm}$, termasuk dalam kategori sedang; dan berdasarkan nilai PV, TBA, TVBN, dan nilai organoleptik pada udang yang direndam ekstrak alga cokelat (Sargassum sp) dan ekstrak daun teh selama penyimpanan dingin memberikan pengaruh nyata terhadap penghambatan oksidasi. Berdasarkan nilai PV, TBA, TVBN, dan nilai organoleptik ekstrak alga cokelat (Sargassum sp) memberikan pengaruh yang lebih tinggi daripada ekstrak daun teh $(C$. sinensis). Selama penyimpanan dingin, udang yang direndam ekstrak Sargassum sp dan ekstrak daun teh dapat bertahan sampai hari ke -12 .

\section{UCAPAN TERIMA KASIH}

Ucapan terima kasih penulis sampaikan kepada semua pihak yang telah membantu dalam terselesaikannya penelitian ini. Penulis juga menyampaikan terima kasih kepada tim editor atas saran dan revisi sehingga naskah ini layak untuk dipublikasikan.

\section{DAFTAR PUSTAKA}

Aminah, S. 2010. Bilangan Peroksida Minyak Goreng Curah dan Sifat Organoleptik Tempe pada Pengulangan Penggorengan. Jurnal Pangan dan Gizi, 1(1).

Andarwulan, N., F. Kusnandar., dan D. Herawati. 2011. Analisis Pangan. Dian Rakyat. Jakarta.

Ananda, A.D. 2009. Aktivitas Antioksidan Dan Karakteristik Organoleptik Minuman Fungsional Teh Hijau (Camellia Sinensis) Rempah Instan. [Skripsi] Fakultas Pertanian Institut Pertanian Bogor. Bogor.

Apriyantono, A., D. Fardiaz., N. L. Puspitasari, Sendarnawati, dan S. Budiyanto. 1989. Petunjuk Laboratorium Analisis Pangan. Institut Pertanian Bogor (IPB Press). Bogor.

Azizah, L.H. 2015. Analisis Kemunduran Mutu Udang Vanname (Litopenaeus vannamei) Secara Kimiawi dan Mikrobiologis. [Skripsi] Fakultas Perikanan dan Ilmu Kelautan Institut Pertanian Bogor. Bogor.

Blois, M.S. 1958. Antioxidant Determinations by The Use of a Stable Free Radical Nature, 181: 1199-1200.

[BSN] Badan Standardisasi Nasional. 1998. Cara Uji Minyak dan Lemak (SNI 01-3555-1998). BSN. Jakarta.

.2006 .

Udang

Segar. (SNI 01-2728.1-2006). BSN. Jakarta.

2009. Cara uji kimia-

Bagian 8: Penentuan kadar Total Volatil Base Nitrogen (TVB-N) dan Trimetil Amin Nitrogen (TMA-N) pada produk perikanan (SNI 2354.8: 2009). BSN. Jakarta.

Dewi, E.N. dan Ibrahim R. (2008). Mutu dan Daya Simpan Filet Dendeng Ikan Nila Merah yang Dikemas Hampa Udara dengan Vacuum Sealer Skala Rumah Tangga. Jurnal Saintek Perikanan, 4: 7-15.

Dewi, E.N., R. Ibrahim, dan N. Yuaniva. 2011. Daya Simpan Abon Ikan Nila Merah (Oreochromis Niloticus Trewavas) yang Diproses dengan Metoda Penggorengan Berbeda. Jurnal Saintek Perikanan, 6(1): 6-12.

Firdaus, M. 2013. Indeks Aktivitas Antioksidan EkstrakRumput Laut Coklat (Sargassumaquifolium). JPHPI, 16(1): 42-47.

Hardiana R., Rudiyansyah, dan T. A. Zaharah. 2012. Aktivitas Antioksidan Senyawa Golongan Fenol dari Beberapa Jenis Tumbuhan Famili Malvaceae. JKK, 1(1): 8-13.

Herliany, N.E., J. Santoso, dan E. Salamah. 2013. Penggunaan Coating Karaginan Terhadap Mutu Organoleptik Udang Kupas Rebus Selama Penyimpanan Dingin. Jurnal Agroindustri ISSN: 2088-5369.

Husni, A., Ustadi, dan A. Hakim. 2014. Penggunaan Ekstrak Rumput Laut Padina sp. untuk Peningkatan Daya Simpan Filet Nila Merah yang Disimpan pada Suhu Dingin. Agritech, 34(3): 239-246. 
Huss, H.H. 1995. Quality and Quality Changes in Fresh Fish. FAO Fisheries Technical Paper No. 348, Food and Agriculture Organization of The United Nation, Rome.

Khotimah K., Darius, dan B. B. Sasmito. 2013. Uji Aktivitas Senyawa Aktif Alga Coklat (Sargassum filipendula) sebagai Antioksidan pada Minyak Ikan Lemuru (Sardunella longiceps). TPHPi Student Journal, 1(1):1020.

Kurade, S.A. and Baranowski, J.D. 1987. Prediction Shelf Life Of Frozen Minced Fish In Terms Of Oxidative Rancidity As Measured By Tbars Number. J. Fd. Sci, 52(2): 300-2.

Lumbessy, M., J. Abidjuju, dan J. J.E.Paendong. 2013. Uji Total Flavonoid pada Beberapa Tanaman Obat Tradisonal di Desa Waitina Kecamatan Mangoli Timur Kabupaten Kepulauan Sula Provinsi Maluku Utara. Jurnal MIPA Unsrat Online, 2(1):50-55.

Martinus, B.A., A. Arel, dan A. Gusman. 2014. Perbandingan Kadar Fenolat Total dan Aktivitas Antioksidan pada Ekstrak Daun The (Camellia sinensis [L] O. K.) dari KAyu Aro dengan Produk The Hitamnya yang Telah Beredar. Scientia, 4(2).

Putranti, R.I. 2013. Skrinning Fitokimia dan Aktivitas Antioksidan Ekstrak Rumput Laut Sargassum duplicatum dan Turbinaria ornata dari Jepara. [Tesis] Manajemen Sumberdaya Pantai Universitas Diponegoro. Semarang.

Putri, A.C.K., dan W. H. Susanto. 2015. Pengaruh Penambahan Ekstrak Daun Teh Segar (Camellia sinensis) Terhadap Karakteristik Kimia Pangan Serta Organoleptik Kacang Pres Goreng Selama Penyimpanan. Jurnal Pangan dan Agroindustri, 3(2): 681-692.

Rafsanjani, M. K. dan W.D.R. Putri. 2015. Karakterisasi Ekstrak Kulit Jeruk Bali Menggunakan Metode
Ultrasonic Bath (Kajian Perbedaan Pelarut dan Lama Ekstraksi). Jurnal Pangan dan Agroindustri, 3(4):14731480 .

Rohdiana, D. 2001. Aktivitas Penangkapan Radikal Polifenol dalam Daun Teh. Majalah Farmasi Indonesia, (1): 5258.

Samin, A.A., N. Bialangi, dan Y. K.Salimi. 2013. Penentuan Kandungan Fenolik Total dan Aktivitas Antioksidan dari Rambut Jagung (Zea Mays L.) yang Tumbuh di Daerah Gorontalo. Jurusan Pendidikan Kimia Fakultas MIPA Universitas Negeri Gorontalo. Gorontalo.

Sampels, S. 2013. Oxidation and Antioxidants in Fish and Meat from Farm to Fork. Intech: 115-144.

Suptijah, P., Y. Gushagia, dan D. R.Sukarsa. 2008. Kajian Efek Daya Hambat Kitosan Terhadap Kemunduran Mutu Fillet Ikan Patin (Pangasius hypopthalmus) pada Penyimpanan Suhu Ruang. Buletin Teknologi Hasil Perikanan, 11(2): 89-101.

Susanto, E. T. W. Agustini., F. Swastawati., T. Surti, A. S. Fahmi, M. F.Albar, dan M. K. Nafis. 2011. Pemanfaatan Bahan Alami Untuk Memperpanjang Umur Simpan Ikan Kembung (Rastrelliger neglectus). Jurnal Perikanan, 8(2):60-69.

Utari, S.A. 2014. Kemunduran Mutu Udang Putih: Organoleptik, Blackspot, Histologis, dan Enzimatis. [Skripsi] Fakultas Perikanan dan Ilmu Kelautan Intitut Pertanian Bogor. Bogor.

Winarno, F.G. 2004. Kimia Pangan dan Gizi. Gramedia Pustaka Utama. Jakarta. 